\title{
建筑工程造价控制与管理研讨
}

尹乐

重庆伟航建设工程有限公司

DOI:10.32629/btr.v1i6.1685

[摘 要] 建筑工程中的造价管理和控制是建筑工程中非常重要的一个环节,现在,中国在建设工程造价管理控制方法还有着 诸多的问题, 有效的控制管理工程造价一定要贯通整个项目的过程。本文探析了建筑工程中造价管理控制的重要性, 并指出了 现在建筑工程造价管理控制中还存有的一些问题,并且给出了相应的解决措施和一些建议, 希望能够给相关专业部门人员提供 一些参考建议。

[关键词] 控制；管理；工程造价

当今, 我国经济处在飞速发展的阶段, 伴随国内经济的 日渐活跃, 建筑行业也在不断的发展中。建筑工程造价的管 理与控制, 直接影响着建筑工程的经济效益。工程造价直接 决定着工程项目的成败, 因此其在建筑工程中具有非常重要 的意义工程造价的确是一个非常复杂的过程, 特别在建筑工 程上, 其产品的多样性和复杂性, 决定了计价方法的多样性 和复杂性。对于政府财政投资的项目来讲, 对工程造价的控 制显得尤为重要, 既要保证好建筑工程项目的建筑物高质量 要求, 又要采取严格及有效的措施合理控制工程造价。

\section{1 工程造价概述}

工程造价的直接含义就是工程的建造价格, 第一种含 义: 是指进行某项工程建设花费的全部费用, 即一项工程通 过建设形成相应的固定资产、无形资产所需用的一次性费用 总和。这一含义是从投资者- - 业主的角度来定义的。投资 者选定一个投资项目, 为了获得预期的效益, 就要通过项目 评估进行决策, 然后进行设计招标、工程招标, 直至竣工验收 等一系列投资管理活动。在投资管理活动中所支付的全部费 用形成了固定资产和无形资产, 所有这些开支构成了工程造 价。从这个意义上说, 工程造价就是工程投资费用, 建设项目 工程造价就是建设项目固定资产投资。

第二种含义: 是指工程价格, 即为建成一项工程, 预计或 实际在土地市场、设备市场、技术劳务市场以及承包市场等 交易活动中所形成的建筑安装工程的价格或建设工程总价 格。工程造价的第二种含义是以社会主义商品经济和市场经 济为前提的。它以工程这种特定的商品形式作为交换对象, 通过招投标、承发包或其他交易形式, 在进行多次性预估算 的基础上, 最终由市场形成的工程价格。

\section{2 建筑工程造价的意义和特点}

建筑工程造价就是工程项目在建设时所消耗的所有成 本费用。主要特点有五点:

2.1 项目资金投入比较大, 要发挥出工程项目建设的投 资作用, 正常来说工程造价的资金都比较大, 像一些特别大 型的项目工程造价甚至都有上百亿的人民币投入。

2.2 建筑工程项目不同工程造价也是不同的。每一个项
目工程都有它独特的用处、功能和范围。另外, 地理位置的 不同也决定了造价的差异化。

2.3 建筑工程造价在实行的时候也不在不停改变的。因 为工程的完成正常会有很长的时间, 在建设的时候因为一些 不可控和未知的原因, 像材料、设备、人工等方面的改变都 会直接影响到工程造价。因此, 工程造价是一直不停的变化 中, 只有工程完工后才能知道准确的造价。

2.4 工程造价有着层次性。工程造价的层次性都是工程 的层次性所决定的。一个工程项目正常都包含着很多个单项 工程, 每一个单项工程又是很多个单位工程所构成的。

2.5 工程造价涉及到的环节非常多, 而且复杂, 利润的形 成也比较复杂, 资金成本投入较大, 所以全方位的把控才能 高效有序的进行。

\section{3 中国建筑工程造价现状和存有的问题}

3.1 工程造价管理控制制度不完善

市场经济中一个非常明显的特点就是用供求关系来优 化资源配置, 不是让政府来规定额度。政府方面大部分都是 经过大方面的调整和引导经济发展等方式。但是现在政府的 政策对工程项目投资的控制很严格。例如, 工程造价的计算 方式还是以定额计价作为中心, 但随着时代的发展, 新型技 术和材料越来越多, 定额已经不能完全满足工程的主要, 在 时间上落后以及在内容上面死板的问题也越来越严重, 工程 项目就会与实际情况出现差异化。

3.2 缺少对工程造价管理的监控

伴着经济全球化的趋向的发展, 现在建筑市场的竞争非 常激励, 又因为现在建筑市场制度还不够完善, 还有一些人 投机取巧, 使用不正当的竞争手法。不按照规定进行, 偷工减 料、以次充好的情况屡见不鲜, 造成了很多工程项目的成本 消耗过多,工程质量不好, 严重影响企业效益等问题。

3.3 工程造价管理人员的素质层次不齐

现在, 从事中国工程造价管理行业的工作人员很多。但 这些工作人员中拥有专业知识、经济管理知识还有工作经验 的专业人才占量一半都没有, 有些是半路出家, 没有一定的 专业知识作为铺垫。这些人员在进行工程造价管理的时候, 
经常都只徘䧃在预算上面, 没有办法深入的进行项目工程核 算和成本分析, 所以对项目造价的影响也尤为严重。

\section{4 建筑工程造价控制和管理的优化措施}

经济社会的改革创新, 建设工程造价不管是在制度上, 还 是在企业领导的观念中甚至人员的素质上都受到了计划经济 时代的影响。所以在强化建设工程的造价管理和控制的创新 上是适应市场经济制度的基础。造价员工要在现在的工作基 础上面使用价值规律, 更好的完善建设工程的造价管理制度。

\section{1 完善法制法规, 转变思想观念}

建设工程的造价管理要遵循法律法规进行, 完善法律法 规, 让建设工程造价管理有法可依。现在中国已经发布了很 多建筑施工企业资质管理方法、招投标法、施工合同法还有 质量管理法等法律法规, 针对工程建设的每个环节都要有对 应的法律规定。加强政府的管理性能, 强化在大方向的调整 能力, 规范化管理建筑市场。

\section{2 建筑工程各环节的造价管理控制 \\ 4. 2.1 招投标环节}

建筑企业要选择适合项目、科学合理的编制标底。依照 项目工程的规模大小、功能性质、特征等, 加入竞争机制, 选择适合的发包方式来控制工程造价。拟定严格精准的招标 文件, 公正公平的进行投招标, 这样能够更加有效的控制工 程造价, 更好的实现市场经济竞争的公平。

\section{2 .2 投资决策环节}

项目的决策对工程造价还有项目完工后给企业带来的 经济效益有着直接关系。工程投资及决策环节是造价控制管 理的开始, 投资所估算的多少直接影响工程造价。唯有科学 规范的估算, 才可以避免出现不必要的消耗。这样才可以保 障项目工程能够按照原定的时间完工。过多过少的估算都会 影响到企业的收益。所以, 在投资决策环节的时候要对工程 进行技术经济的论证, 比较不同方案, 进而更好的保证造价 的准确和客观。

\subsection{3 设计环节}

设计环节直接影响着工程项目的投资规模, 是造价中非 常重要的环节。设计人员的方案不但要保证施工技术的可操 作, 还要在经济上更加合理。完善和改良现有的设计方案和 招标方法, 成立科学规范的设计竞争制度, 选用合适的企业 和人员。优化改良设计方案, 不但要多多使用新型技术工艺, 还要减少投资加大和超出。尽量不要更改设计方案, 除了非
常紧急问题需要变更, 严禁擅自修改设计方案, 扩大规模等。

(1) 限额的设计

所谓限额设计就是先按照上述准备过程中批准的可行 性研究报告的总概算控制技术设计和施工图设计, 在这个过 程中要兼顾好资金和功能的平衡, 在限制资金的同时还要去 满足功能的实现。严格执行分配的投资限额控制设计, 以便 能充分保证总投资额不被突破。控制工程造价采用限额设计, 就是为了防止工程造价超出了之前的投资预算。限额的设计 不但实现对投资限额的控制和管理, 还实现了工程数量和概 预算指标等很多方面的控制, 它是工程造价的整体约束。

(2) 优化设计方案

在确定该建筑项目可行的情况下, 就是要保证设计质量 达到国家的规定, 因为这个方案在一次性投资以后是要进行 使用和产生经济效益的, 所以, 搞好工程设计阶段的造价控 制是有效控制工程造价的关键。在对工艺技术方案进行优化 的时候, 要根据我国城市和地方的实际情况, 在提高投资效 益的前提下, 多采用先进的技术方案和成熟的新技术、新工 艺。目前, 现实中经常会发现存在重施工、轻设计的观念, 这是必须要避免的。设计部门一定要认真地进行经济分析, 去制定出经济合理、切实可行的设计方案。

\section{5 结束语}

总之, 我国经济体制不断深入改革, 工程造价应用在建 筑工程管理技术中也变得特别重要。工程造价是投资的最主 要的内容, 其中囊括了从工程项目建设设计阶段到建设完成 所需要花费的所有费用。价格机制是管理工程造价应用的核 心, 通过良好的造价管理, 可以使企业的造价管理在水平上 得到提高, 也可以提高企业的经济效益, 从而使得工程造价 在建筑工程管理中发挥重要的作用。因此, 对工程控制中存 在的各个施工要点综合性进行控制, 对建筑工程造价管理中 各阶段的控制性工作的加强, 才可以使得工程造价管理控制 工作能够在现代社会下, 更好地开展管理控制工作。

\section{[参考文献]}

[1]陈路生.建筑工程造价控制与现场管理探讨;现代商 贸工业,2011(07):35.

[2]刘文娟.建筑工程造价控制存在的问题与对策措施; 商业经济,2011(03):52.

[3]马斌.电力工程的造价管理与控制对策分析[J].集成 电路应用,2019(01):113-114. 